\title{
APROPRI[AÇÕES]: DAS FAGULHAS ACIONADAS POR ENCONTROS COM IMAGENS FÍLMICAS, ESCRITAS E DOCÊNCIAS...
}

\author{
APPROPRI[ACTION]: ON THE SPARKS TRIGGERED BY ENCOUNTERS WITH FILMIC IMAGES, WRITINGS AND TEACHING..
}

APROPI[ACCIONES]: DE LOS DESTELLOS ACCIONADOS POR LOS ENCUENTROS CON IMÁGENES FÍLMICAS, ESCRITURAS Y ENSEÑANZAS...

\author{
CARDONETTI, Vivien Kelling ${ }^{1}$ \\ GARLET, Francieli Regina² \\ OLIVEIRA, Marilda Oliveira de ${ }^{3}$
}

\begin{abstract}
RESUMO
Este artigo buscou experimentar diferentes fluxos de pensamentos em relação à docência, a partir de dois movimentos que se entrecruzaram: o primeiro referente às materialidades (escritas e imagens) produzidas em uma experiência educativa, no processo de apropriação de três imagens fílmicas que não propriamente diziam de docência e educação; e o segundo relativo à ação de apropriação empreendida na escrita desse artigo quando em contato com essas materialidades. A perspectiva cartográfica de investigação impeliu as autoras a investir em linhas transversais traçadas junto a problemática: como movimentos de apropriação podem conferir à docência e a educação outras possibilidades de existência?
\end{abstract}

Palavras-chave: Apropriação. Imagem fílmica. Educação. Criação de docências.

\section{ABSTRACT}

This paper aimed to try out different flows of thought related to teaching through two movements that are interrelated: the first one refers to materiality (writings and images) produced in an educative experience, in the process of appropriation of three filmic images that were not concern about teaching nor education directly; and the second one is related to the action of appropriation in the process of writing this paper, which is related to that materiality. The cartographic research perspective made the authors invest in transversal lines built along with the problem: how do movements of appropriation can cause another existing possibility about teaching and education?

Keywords: Appropriation. Filmic images. Education. Creation of teaching processes.

\section{RESUMEN}

Este artículo buscó experimentar diferentes flujos de pensamientos en relación con la docencia, a partir de dos movimientos que se entrecruzan: el primero es sobre las materialidades (escritas e imágenes) producidas en una experiencia educativa, en el proceso de apropiación de tres imágenes fílmicas que no propiamente hablan sobre docencia y educación; y el segundo se refiere a la acción de la apropiación emprendida en la escrita de este artículo mientras se tenía contacto con esas materialidades. La perspectiva cartográfica de investigación condujo a las autoras a invertir en líneas transversales trazadas junto a la problemática: ¿Cómo movimientos de apropiación pueden infligir a la docencia y a la educación otras posibilidades de existencia?

Palabras clave: Apropiación. Imagen fílmica. Educación. Creación de enseñanzas.

\footnotetext{
${ }^{1}$ Universidade Federal de Santa Maria - UFSM - Santa Maria - Rio Grande do Sul - Brasil.

2 Universidade Federal de Santa Maria - UFSM - Santa Maria - Rio Grande do Sul - Brasil.

${ }^{3}$ Universidade Federal de Santa Maria - UFSM - Santa Maria - Rio Grande do Sul - Brasil.
} 


\section{APROPRIAÇÕES QUE GESTAM ESSA ESCRITA...}

O presente artigo é composto de encontros. Encontros que nascem em meio a docências que atravessam uma experiência educativa em um Curso de Licenciatura em Artes Visuais, mas, também, em meio a uma escrita produzida por seis mãos e por muitos outros corpos/pensamentos. Escrita que toma como movimento o conceito de apropriação (CHIARELLI, 2002; OLIVEIRA, DAHMER, 2017; KNAAK, 2005), fazendo funcionar 'com' ele imagens fílmicas, escritas e docências costuradas por um pensamento que não se sabe antes do encontro, pois é da ordem do acontecimento.

Buscamos, portanto, movimentar no texto que segue o conceito de apropriação junto às experimentações com escritas propostas no decorrer da disciplina Cinema e Educação (Prática Educacional VIII), ministrada pela primeira e terceira autora desse texto, no ano de 2016, na Universidade Federal de Santa Maria. Disciplina na qual foram trabalhados oito filmes, com o intuito de acionar [im]possíveis conexões com a educação e a docência. Referimo-nos aos [im]possíveis ao comungarmos com Deleuze quando menciona que podemos "falar da criação como traçando seu caminho entre impossibilidades" (DELEUZE, 2010, p. 171), ou ainda quando o autor escreve que "um criador é alguém que cria suas próprias impossibilidades, e ao mesmo tempo cria um possível" (Ibidem, p. 171). A ideia, portanto, era acionar por tensionamentos e [im]possibilidades uma docência pensada desde outros lugares (com imagens fílmicas que não diziam diretamente de docência, que não ilustravam uma docência) um possível a ser forjado em meio a aparentes impossibilidades de conexão...

Assim, as escritas que compõem o foco de estudo e exploração desse artigo foram produzidas por uma das acadêmicas da disciplina que, ao se apropriar de três produções cinematográficas trabalhadas no decorrer do semestre: 'Onde fica a casa do meu amigo?' (direção de Abbas Kiarostami, 1987), 'Tempo de embebedar cavalos' (direção de Bahman Ghobadi, 2001) e 'O balão branco' (direção de Jafar Panahi, 1995), passou a produzir uma interlocução com a docência e a educação.

Portanto, interessa-nos, nesse texto, um movimento operatório que é também o de apropriação com relação à escrita da referida acadêmica. Uma apropriação, enquanto um 'habitar', um 'ocupar', um 'friccionar' essa produção com uma atenção à espreita do que pode ainda disparar em nós, enquanto movimentos de escrita e de criação de outros [im]possíveis em meio à educação, à docência e a nós mesmas...

As perguntas-problemas que nos chegam e nos arrastam junto desse movimento de apropriação que permeia esse artigo, dizem respeito à: Como um movimento de apropriação de imagens fílmicas que não propriamente dizem de docência e de educação podem conferir à docência e a educação outras possibilidades de existência? Como manter pulsante aquilo do qual nos apropriamos? Como produzir um encontro com a parte ainda 'sem dono', ainda por se fazer da docência e da educação?

Ao mencionar 'sem dono', referimo-nos aqui à parte das coisas ainda em estado de virtualidade, para Deleuze (2006), todos os objetos possuem metades desiguais de atuais e virtuais, o que eles são a cada vez (ou o que temos como dado, pronto sobre ele) e o potencial de vir a ser outras coisas ainda não imaginadas. Supomos que ao nos apropriarmos de algo, no movimento de criação 
que essa ação implica, habitaríamos a parte virtual das coisas, a parte em que podemos acionar outras produções de sentidos, que escapam ou fazem vazar o que já está dado sobre elas. Segundo Corazza

\begin{abstract}
entre uma linguagem e outra [...] existem pontos de silêncio, vazios de linguagem, vácuos de ângulos classificatórios, pontos de vista não perspectivados, enunciados ainda a serem articulados. [...] Só aqui é possível produzir abalos; provocar mudanças no que somos capazes de ver e de dizer; dar alegres cambalhotas; radicalizar nossas relações com o poder e o saber; partir as linhas; mudar de orientação; desenhar novas paisagens; promover outras fulgurações. Enfim, artistar, inventando novos estilos de vida e, portanto, de práticas" (CORAZZA, 2007, p. 122).
\end{abstract}

Corazza, nessa passagem, convida-nos a olhar para a docência como um espaço de criação que provoca a experimentar o mundo uma e outra vez e, também, a partir do que não está dado sobre ele. O processo de apropriação pode contribuir desta maneira, para que venhamos a "nos apropriar daquilo que nos cerca e produzir outros sentidos" (OLIVEIRA; DAHMER, 2017, p. 78). Ao habitar essa zona de vizinhança, passamos, de algum modo a engendrar também um movimento de apropriação de nós mesmos, implicando, assim, na abertura de infinitas possibilidades de sermos diferentes do que somos.

APROPRI[AÇÕES]... APROP[RIAR-SE]...

Sim, sou um ladrão de pensamento não, por favor, um ladrão de almas eu construí e reconstrui sobre o que está à espera pois a areia nas praias esculpe muitos castelos no que foi aberto antes de meu tempo

uma palavra, uma ária, uma história, uma linha chaves no vento para que minha mente fuja e fornecer a meus pensamentos fechados uma corrente de ar fresco (...) [Bob Dylan]

O que nos resta diante de um mundo em que tudo parece já ter sido dito e visto? Um mundo em que a docência e a educação já parecem ter esgotado suas infinitas possibilidades de existir? $\mathrm{O}$ que fazer com o que já está aí, com o que já foi produzido a respeito de docência, de educação, de vida?

Compor, recompor, apropriarmo-nos. Sujarmos de nós o que já está aí, compor com eles outros [im]possíveis. Compor com as coisas desse mundo, em movimentos micro, outros mundos dentro do mundo (DELEUZE, 2006). Atentar para o que de singular emerge do nosso encontro com o que já está posto.

O termo apropriação diz respeito aqui a um apropriar-se daquilo que originalmente não nos pertence (KNAAK, 2005) e acrescentar outros focos de luminosidade, intensificando sua potência e colocando em incessante movimento. Um roubo, ao modo deleuziano (DELEUZE; PARNET, 1998), um modo de fazer algo fugir...

\footnotetext{
${ }^{4}$ In: DELEUZE; PARNET, 1998, p. 15.
} 
Para Chiarelli (2002), o conceito de apropriação está baseado na ideia de que:

\begin{abstract}
Apropriar-se não significa, em princípio, apropriar-se de apenas um ou dois objetos ou imagens da mesma natureza, ou com uma ou várias características comuns. Apropriar-se é matar simbolicamente o objeto ou a imagem, é retirá-los do fluxo da vida - aquele contínuo devir, que vai da concepção/produção até a destruição/morte - colocando-os lado a lado a outros objetos, com intuitos os mais diversos (CHIARELLI, 2002, p. 21).
\end{abstract}

Chiarelli acrescenta que pensar o conceito de apropriação é "elevar os seus sentidos a partir do seu deslocamento para outros espaços, juntando-o a elementos diversos" (2002, p. 21). Nesse sentido, podemos pensar a produção de um 'entre' enquanto um terreno 'sem dono' que perpassa essas composições e conexões.

À vista disso, mais algumas questões emergem dessas conversações: Também podemos nos considerar um desses elementos nessa composição? Podemos pensar o que se desloca em nós nesses encontros? O que nos acontece em um processo de apropriação? Em um apropriar-se? Como entramos nessa composição? Como nos sujamos dela? O que escapa e escorre de nós nessas composições?

Esses questionamentos nos instigam a brincar/experimentar algumas variações na palavra apropriação:

- Apropri[ações]... colocar em ação/movimento, desde si $^{5}$, o que já está adequado, confortável, considerado próprio...

- Aprop[riar-se], fazer-se rio, escorrer de si, 'riar-se'...

Antes de tomar o termo apropriação a partir da ideia de um eu já definido que toma algo para si, com vistas a exercer um poder sobre aquilo do qual se apropria, interessa-nos uma relação de produção de potências gestadas transversalmente (não verticalmente e tampouco horizontalmente) nesse encontro. Apropriar-se, aqui, diz, talvez, mais respeito a produzir moradas e sentidos provisórios em terrenos ainda sem donos, ainda não definidos, para que outras fagulhas, ou correntes de ar possam arrastar as formas que já estão dadas... Diz de de(morar)-se na parte sem dono, indefinida e selvagem das coisas que arrasta todas as instâncias envolvidas, que modificam aquilo que é apropriado e também aquele que se apropria, que faz nascer em ambos o desejo de partir, de descolar-se de onde se está... para segu[ir]... dev[ir]... Ir...

Ao explorar a experiência vivenciada na disciplina com as imagens fílmicas, junto a esse conceito de apropriação, passamos a ser impelidas a pensar que tais imagens se deixaram arrastar pela visão dos acontecimentos e pelas exigências em cena, impulsionando o atravessamento de variáveis fluxos de forças. Por estarem imbricadas nas contingências de cada encontro, passaram a ser provisórias, mutantes, sempre em deslocamento.

É no sentido de colocar em movimento tais aspectos pontuados que o conceito de apropriação foi convidado a se fazer presente nesta escrita. A apropriação é vista na investigação como algo que

\footnotetext{
${ }^{5} \mathrm{O}$ si como "extremidade prolongada do Caos, das forças [...]" o que difere da noção de 'eu' enquanto "prisioneiro da gramática, das suas funções". Si, como "fora estrangeiro que cada um carrega consigo" (PELBART, 2016, p. 68), dobra.
} 
nos permite visitar o instituído da imagem fílmica ou de qualquer outro elemento, fazendo um movimento de atualização ${ }^{6}$ e conferindo fissuras na linearidade temporal e em certas verdades discursivas. Isso instiga a pensar nas inúmeras possibilidades que podem ser inventadas com a aproximação, a aliança, o tensionamento e o embaralhamento de elementos heterogêneos, como imagens fílmicas, educação e docências em formação, pois propicia a intervenção no que está posto, a exploração de novos ângulos e a criação infinita de outras séries e arranjos.

Levando em consideração essas colocações, outras questões passaram a transversalizar e inquietar a escrita desse texto: Que maquinarias são postas para funcionar no emaranhado entre docência, educação e imagem fílmica? De que modo essa maquinaria pode injetar potências na docência, na educação e nas imagens fílmicas a cada vez? Que outras potências de existir são acionadas nelas nesse processo? $\mathrm{O}$ que acontece quando uma aula que quer pensar o cinema e a educação, escapa a uma abordagem pedagógica da imagem fílmica?

\section{APROPRI[AÇÕES] DE IMAGENS FÍLMICAS}

A presença da imagem fílmica em meio às experiências educativas tem atravessado alguns campos de estudo e de experimentações nos últimos tempos, para citar alguns: Adriana Fresquet (2013, 2015), Alice Fátima Martins (2014), Lutiere Dalla Valle (2014) e Valeska Maria Fortes de Oliveira $(2016,2017)$. Em meio a esses estudos tem nos interessado algumas vias tomadas por autores que se aproximam e são movimentados pelas filosofias da diferença, como César Donizetti Pereira Leite (2014), Fabiana de Amorim Marcello (2008), Jorge Vasconcellos (2006; 2008), Antônio Carlos Rodrigues de Amorin $(2007,2018)$ e Marilda Oliveira de Oliveira (2014). Dentre as inúmeras possibilidades existentes, o cinema pode ser visto como um campo de experimentações do pensar, uma 'máquina de pensar' (DELEUZE, 1990), pois "mais importante do que o pensamento é aquilo que faz pensar" (DELEUZE, 2010, p. 29). Nesta direção, Vasconcellos (2008, p. 160) acrescenta que "tanto filósofos como cineastas estão no campo problemático do pensamento, porém, o filósofo constrói conceitos, enquanto o cineasta, por sua vez, lança-se na invenção de imagens".

É esta perspectiva que nos interessa explorar nesta escrita, pois o cinema, por ser uma matéria pensante, uma matéria inteligível, pode impulsionar a criação de pensamentos, propiciando atuar no mundo apresentado e no cotidiano alheio. Ao "experimentar outras vidas, posse transitória, troca de personagens; sair de si e morar nos espaços suspensos pela ausência" (ROMAGUERA; SANCHES; AMORIM, 2010, p. 1683), passamos a experienciar mundos que pareciam inviáveis. Essa experiência propicia que ampliemos as perspectivas do nosso cenário existencial, instigando-nos a pensar de forma diferente e a agir de outro modo.

Deleuze (2010, p. 80) afirma que "o cinema é produtor de realidade". Essa colocação nos faz pensar que a experiência ao assistir a um filme é real, pois as cenas e as sensações são mostradas de forma que venhamos a sentir, a vivenciar e nos produzir a cada momento. Nesse viés, as imagens fílmicas ou os signos fílmicos podem ser encarados como disparadores de provocações que

\footnotetext{
${ }^{6} \mathrm{~A}$ atualização diz respeito, aqui, a um movimento de variação, de produção de uma diferença que se dá a partir de um recorte de uma virtualidade (DELEUZE, 1999).
} 
impulsionam a possibilidade de olhar de outro modo para determinados hábitos do pensamento ainda arraigados e solidificados em nós.

Dessa forma, temos investigado possibilidades que se distanciam do uso pedagógico e instrumental dos filmes ${ }^{7}$, na qual a ênfase se coloca muitas vezes em uma moral a ser decifrada e apreendida ou no reforço de ilustrar algum conteúdo que se deseja trabalhar. Ela aposta em outra via, pois a intenção é pensar nos afetos ${ }^{8}$ e possibilidades de relações que podem ser estabelecidas a partir dos signos emitidos pelo filme e pela atmosfera acontecimental do encontro.

À vista disso, a intenção foi ensaiar algumas experimentações escritas e visuais com as imagens fílmicas trabalhadas na disciplina Prática Educacional VIII, buscando não um pensar com ideias acabadas e definidas previamente, "mas ideias que possam compor outras ideias, outras cenas que possam ser apresentadas, bricoladas, montadas, desmontadas, plurais" (LEITE; CHRISTOFOLETTI, 2015, p. 44).

Em vez de serem interpretadas, as imagens fílmicas passaram a nos oferecer singulares relações com a docência e com a educação, pois elas ressoaram em múltiplas direções e sentidos, convidando-nos a engendrar diferentes experimentações. Ao tirarmos proveito de sua faculdade plural, elas foram impelidas a outras imagens, diversamente do sentido representativo, em que as imagens voltam para si mesmas. Esta faculdade múltipla contribuiu para sua profusão e dispersão. Isto nos faz pensar que "uma imagem nunca está só. O que conta é a relação entre as imagens" (DELEUZE, 2010, p. 71-72).

Dessa forma, é possível afirmar que é no interstício, no 'entre' das imagens fílmicas que muitas coisas podem ser cruzadas e construídas. É neste espaço aberto que alianças são concebidas e que inesperadas construções de sentidos são inventadas, fazendo-nos compreender que a maneira de se relacionar com a imagem fílmica não depende exclusivamente do olhar do observador, tampouco somente do que é visualizado, e sim daquilo que foi possível de ser produzido neste tensionamento, na apropriação desse espaço 'sem dono', que se dá no entre das conexões.

Pensando que a relação com a imagem fílmica é singular e que estará enredada pelas contingências do momento, passamos a questionar: quando solicitado aos/as acadêmicos/as que fizessem gestos de suspensão nos filmes para possíveis problematizações, que fragmentos foram elencados por eles? Que relações os acadêmicos estabeleceram nestes cruzamentos e justaposições? Que criações os acadêmicos se aventuraram a produzir nestas experimentações escritas e visuais?

Para além das imagens mostradas numa tela, está a problematização, a apropriação, o tensionamento com outros elementos. É neste 'entre', por vezes silencioso, potente, vazio e ao mesmo tempo povoado que o ato da criação se faz presente. Criação que é produzida ao experimentar e que também passa a ser "um processo de autocriação, de criação de si; ou seja, um diferenciar, diferenciando-se" (CORAZZA, 2013, p. 98). No caso da disciplina, um inventar-se docente junto das

\footnotetext{
7 Algumas dessas experimentações podem ser acessadas nas seguintes publicações: (CARDONETTI, 2014), (CARDONETTI; OLIVEIRA, 2019),, (CARDONETTI; OLIVEIRA, 2017), (OLIVEIRA, 2015), (CARDONETTI; GARLET; OLIVEIRA, 2014)

8 Afeto é entendido nessa escrita a partir de Spinoza (2016) e Deleuze (1978, online), como variações nas potências de existir a partir dos encontros que temos e, também, como "um modo de pensamento não representativo" como algo que é acionado, disparando devires...
} 
imagens fílmicas e das produções visuais e escritas que emergiam desse encontro insuspeito entre cinema, docência e educação.

A possibilidade de alterar o estado das coisas, possibilita viver o ato da criação e resistir ao modelo da verdade. Nesse viés, Pelbart (2007) convida dois filósofos para problematizar a questão do ato da criação e da resistência. $O$ autor oferece na citação a seguir uma curiosa interpretação de Agamben sobre as colocações de Gilles Deleuze (1987) numa conferência sobre cinema ('O que é ato de criação?').

\footnotetext{
Mas o que significa resistir? É antes de tudo ter a força de des-criar o que existe, des-criar o real, ser mais forte do que o fato que aí está. Todo ato de criação é também um ato de pensamento, e um ato de pensamento é um ato criativo, pois o pensamento se define antes de tudo por sua capacidade de des-criar o real (PELBART, 2007, p. 7).
}

Como observa Deleuze (2010, p. 183), "criar não é comunicar mas resistir", é crer que é possível fazer algo, é inventar outras vias no seu campo de atuação, é investir em 'linhas de fuga' (DELEUZE; GUATTARI, 2008), pois ao fazer isso traímos as significações hegemônicas e criamos outros sentidos e potências de vida. Não precisamos aguardar que as grandes rupturas nos cheguem prontas, elas podem acontecer no âmbito da educação menor, em microfissuras onde se possa habitar/experimentar uma terra sem dono. Cada um de nós pode pensar/criar/resistir, atuando no cenário que nos compete e com as ferramentas de que dispomos no momento.

\section{A METODOLOGIA QUE NOS ACOLHEU...}

Cada pesquisa possui sua metodologia ou suas metodologias, é uma relação de envolvimento com aquilo que vai produzindo sentido. Ela vai abraçando o pesquisador, acolhendo-o e o capturando, vai se construindo durante o percurso, tomando parte desse processo a partir de uma experiência que se desloca. Nesse sentido, com a intenção de atender aos anseios da investigação, optamos pela perspectiva cartográfica de investigação, que abriga uma aventura transversal de movimentação.

Apresentada por Gilles Deleuze e Félix Guattari (1995a) na introdução de seu livro Mil Platôs Capitalismo e esquizofrenia - Vol. 1, a cartografia é uma abordagem de investigação que aposta na experimentação e não na aplicação de procedimentos metodológicos. Nessa perspectiva, a cartografia passa a ser encarada como "um desenho que acompanha e se faz ao mesmo tempo que os movimentos de transformação da paisagem" (ROLNIK, 2006, p. 23).

Ou seja, trata-se de uma pesquisa que se faz "no decorrer do caminho, na própria caminhada, de acordo com as necessidades instauradas pelo relevo imposto pelo percurso" (OLIVEIRA; MOSSI, 2014, p. 193). Contudo, vale salientar que não é um caminhar sem direção ou sem sentido, trata-se de primar por um trilhar que vai construindo o trajeto e é construído por ele, a partir de afetos que se produzem a cada vez e vão produzindo o percurso.

É por isso que a investigação do processo de produção é tão cara para a cartografia, pois é no percurso que vão se produzindo os dados da pesquisa. Nesse viés, não há nada a ser descoberto, 
desvelado ou reproduzido, mas um terreno em constante movimento a ser experimentado e cartografado.

O campo coletivo de forças da investigação passou a ser redesenhado constantemente no decorrer da disciplina de Cinema e Educação, com cruzamentos transversais de imagens fílmicas que não propriamente diziam de docência e de educação, mas que possibilitaram pensar outras vias em relação à docência e à educação. Tais movimentos que seguem nessa escrita buscam apostar na dinâmica da transversalidade, redesenhando paisagens e instaurando outros [im]possíveis.

O conceito de 'transversalidade' foi proposto por Guattari em 1964, servindo-lhe, inicialmente, para pensar "o movimento de abertura comunicacional, de desestabilização dos eixos dominantes de organização da comunicação nas instituições" (PASSOS; BARROS, 2015, p. 155). Como coloca Passos e Eirado, o movimento transversal viabiliza "uma experiência de comunicação que faz variar os pontos de vista, mais do que abolí-los” (2015, p. 116-117), circunscrevê-los ou cerceá-los. Por isso é que a transversalidade faz uso da conjunção 'e', abrindo a possibilidade de explorar novas conexões e facultando outras tessituras. Potencializa, também, a vinda do que não se pode prever, abrindo-se a situações inimagináveis e estando receptiva ao que não é rotineiro.

Gallo (2014, p. 195) expõe que a

\begin{abstract}
transversalidade constitui, pois, a forma de fluxo e de encontros entre as singularidades em um rizoma. Sem hierarquia, sem imposição, sem dominação, sem unidade. Multiplicidades singulares agenciadas, conectadas, produzindo encontros e possibilidades.
\end{abstract}

Ou seja, a transversalidade seria o modo de mobilidade por entre os liames de um rizoma ${ }^{9}$. De modo que os saberes, a partir de suas singularidades, passam a se conectar e se misturar conforme seus interesses e necessidades.

Nessa direção, o investimento nas linhas transversais, traçadas durante as experiências educativas com as imagens fílmicas e os movimentos de escrita, tiveram o intuito de desestabilizar os eixos cartesianos - vertical/horizontal (GUATTARI, 2004), onde as formas se apresentam previamente categorizadas e aguardadas, pois o eixo vertical tem como premissa a hierarquização da comunicação dos diferentes e o eixo horizontal tem a homogeneização da comunicação na corporação dos iguais (PASSOS; EIRADO, 2015).

A intenção, com essa metodologia, foi apostar nesse tracejar transversal, que diz respeito, nesse artigo, às apropriações de diferentes imagens fílmicas, às práticas de escrita em sua força de invenção de outros sentidos, testemunhando o protagonismo em criar possibilidades de docência e de educação que nunca se fecham, mas seguem abertas a outros [im]possíveis de existência.

\title{
FAGULHAS DE ESCRITAS E IMAGENS FÍLMICAS...
}

\footnotetext{
${ }^{9}$ Conceito criado por Deleuze e Guattari e apresentado em Mil Platôs - Capitalismo e esquizofrenia - Vol.1 como um mapa aberto, no qual "qualquer ponto de um rizoma pode ser conectado a qualquer outro e deve sê-lo. $E$ muito diferente da árvore ou da raiz que fixam um ponto, uma ordem" (DELEUZE; GUATTARI, 1995a, p. 15), em que a estrutura, a sequência e a evolução estão presentes. No rizoma não existe um centro consolidado a que todos os elementos devem se reportar, busca-se justamente o descentramento dos envolvidos.
} 
Nos encontros semanais da disciplina - Cinema e Educação (Prática Educacional VIII) interessavam os movimentos acionados pela apropriação de espaços 'entre' imagens fílmicas, docências, educação e dos sentidos (moradas provisórias) que iam sendo produzidos e cartografados junto às escritas e às visualidades. Fagulhas de escrita se descolam do espaço dessa experiência e, em outra temporalidade, seguem a disparar outros escoamentos, produzindo outros 'entres'. À vista disso, nesse texto, parece ser oportuno nos ocupar dos movimentos acionados pelo encontro com escritas e imagens gestadas por uma das acadêmicas naquele momento da disciplina. Interessa-nos, apropriarmo-nos desse 'entre', essa terra sem dono (por se fazer), que esse outro encontro produz entre nós - duas professoras da referida disciplina ( $1^{\mathrm{a}}$ e $3^{\mathrm{a}}$ autoras) e uma estrangeira à disciplina ( $2^{\mathrm{a}}$ autora) que se colocam a experimentar, desde outro tempo e lugar, as fagulhas dessa experiência que permanecem em potência.

Sobrepomos, assim, camadas temporais e de experiências, de modo a fabricar 'entre' elas outras apropri[ações] e aprop[riarmo-nos] nesse processo.

Apropri[ação], aprop[riar-se]... Ocupar-se... Diz respeito, assim, a fazer uma morada provisória na parte das coisas que se encontra ainda sem dono. Alojar-se na parte indefinida das palavras, das imagens, da docência, da educação e ficar então à espreita de suas faíscas de potência... Alojar-se no intervalo da relação...

Isso vem ao encontro da escrita da acadêmica Ana Paula Greine, quando menciona a respeito de sua experiência com três das imagens fílmicas trabalhadas na disciplina:

Não é o objeto.

Não é o sujeito.

... É a relação!!!!!

Tempo de admitir:

Admito que busquei saber sobre o significado daquele balão branco. Admito que tive a intenção de entender por que era tempo de embebedar cavalos.

Admito que inicialmente busquei achar uma casa10

Entretanto, junto dessa busca por uma lógica pré-determinada - a qual estamos acostumados também havia uma escuta às possibilidades inesperadas que acionaram outras fagulhas de [im]possíveis com escritas e imagens.

Figura 01 - Imagens do diário visual da acadêmica Ana Paula Greine, produzido durante a disciplina "Cinema e Educação (Prática Educacional VIII)"

\footnotetext{
10 Fragmentos de escritos da acadêmica Ana Paula Greine, na disciplina Cinema e Educação - Prática Educacional VIII (2016) serão trazidos nessa seção do texto sempre em itálico e alinhados à direita.
} 


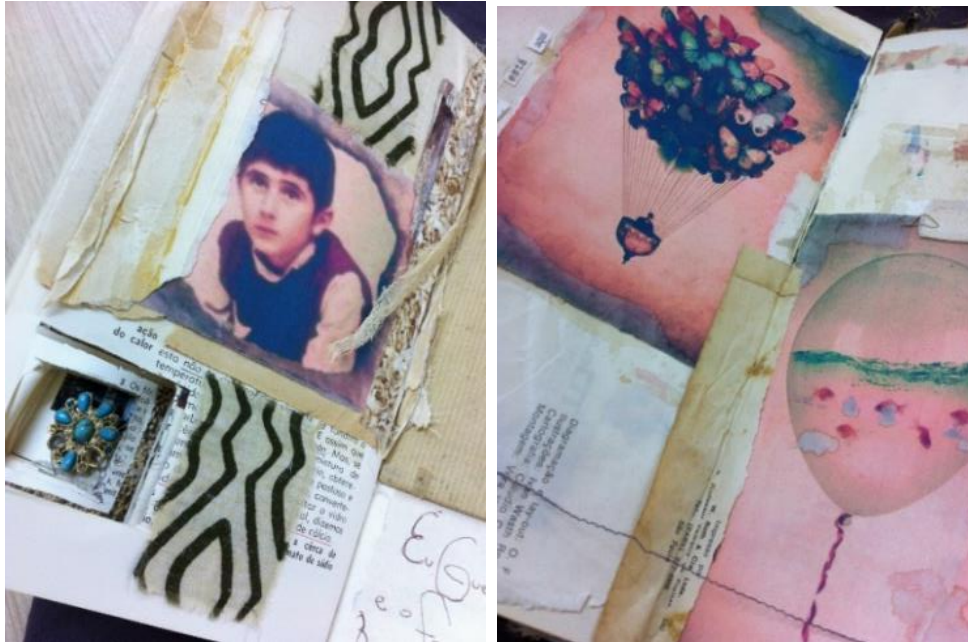

Fonte: Acervo pessoal da acadêmica Ana Paula Greine.

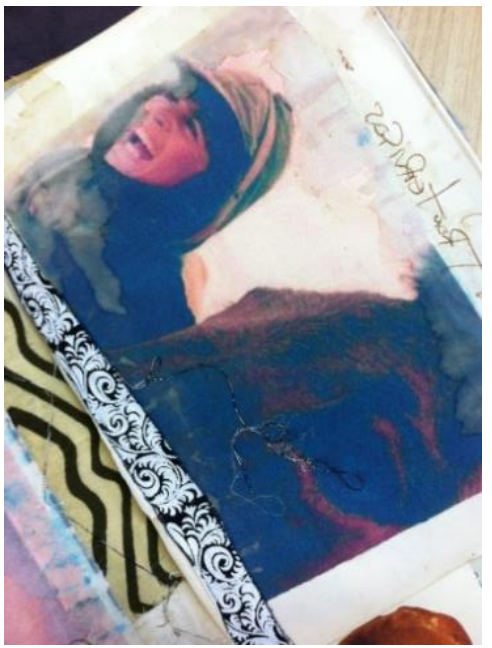

Qual o lugar da educação? Existe um?

Onde fica a casa da educação?

Não sei. Ahmad também não sabia onde ficava a casa de seu amigo, muito embora não deixou de buscá-la, de persegui-la, de traçar seus caminhos até ela, de configurar com a diferença da repetição (DELEUZE, 2006) seu inusitado trajeto. Ahmad percorreu Em vias de. Em linhas de. Em devires de. Em uma sinuosa estrada rotas de. Não seria prolífero para mim, Ahmed e a Educação completar as lacunas, fechar um final, identificar um substantivo, enfim, encontrar uma casa. Não seria oportuno, para mim, descobrir o lar da educação, onde ela dorme e que horas faz suas refeições. Interessa-me por onde ela anda, por quais terrenos foge quando lhe pedem rendição, qual esfera plurifacetada mostra quando Ihe fazem juras de habitação, por quais conjecturas de desvencilhamento responde quando é pega em armadilha e improviso. Quero saber onde ela dança, onde compõem suas delirantes poesias, quero saber sobre os corpos dos quais se utiliza para diferir-se de si (FOUCAULT, 2004), quero correr atrás da cara que mostra para seus vaidosos enjauladores: audaciosa. Embarquei, com Ahmed, à procura de uma casa. Percebi, com Ahmed, que a casa era o que menos queria encontrar. Eu queria era o fervor e o frescor da procura. Eu ainda os quero.

Procurar uma casa e encontrar-se com um lugar ainda sem dono, produzido no 'frescor da procura'... Há que se produzir/inventar a casa e ao mesmo tempo manter em potência um lugar de ninguém... Dar consistência sem perder o infinito, diriam Deleuze e Guattari (1992). Como inventar microespaços para nascer de forma inesperada, em meio as casas demasiado prontas e vigiadas que 
encontramos em nossos percursos educativos? Como inventar-se docente clandestino/a e aventureiro/a em casas que há muito tempo residimos e nas quais costumamos habitar sempre de um mesmo modo?

"Seres fronteiriços [...] são seres em trânsito para outra coisa" (LARROSA, 2006, p. 62). Larrosa me falava sobre os Curdos, sobre as fronteiras e sobre o Tempo de embebedar cavalos. Gobhadi me falava sobre sobrevivência. Ayub e Madi me falavam sobre resistência.

Eu quero te falar - por mim - sobre o ser (sobrevivente) - em - trânsito (resistente) - docente. Que a ideia de ser - sobrevivente reporta-me aos movimentos que fazemos; que os movimentos que fazemos me dizem sobre nos colocarmos em trânsito; que nos colocarmos em trânsito também concerne a produzirmos resistências; que produção de resistências possuem íntimos diálogos com a docência: resistimos, não transformamos. Criamos nossos micros espaços de resistências dentro dos macros espaços. Não quero ser pretensiosa por demais: transformar a todos e idealizar que alcancemos todos

o mesmo resultado e que sejamos os mesmos às mesmas maneiras é possivelmente um boicote ao ser outro, ao ser em trânsito para outra coisa; ao docente outro! Não tenho a intenção de ser-docenteoutro buscando o mínimo múltiplo comum, mas o máximo múltiplo diverso. E, para isso, motivei-me com Ayub a ser fronteiriça, a me colocar em trânsito em busca das outras coisas, das outras Anas, das outras professoras que podem ser acionadas em mim, das minhas outras docências possíveis, de minhas outras resistências quando preciso sobreviver e o ambiente é inóspito, o frio é intenso e a viagem é longa.

Resistir...

Habitar a superfície da nossa própria pele, essa fronteira porosa onde afetos pedem passagem... Essa fronteira ambulante de um 'si' em constante produção, onde o mundo percussiona ritmos variados a cada vez, onde marcas se produzem, respiros acontecem, camadas se soltam... Como 'salvar a pele' docente do entupimento de poros, como preservá-la enquanto espaço de passagem, superfície acontecimental que se deixa afetar pelos encontros? Como salvá-la das camadas duras de um eu docente demasiadamente formado? Como deixá-la ir com aquilo que a faz escamar a cada vez?

Resistir... rEXISTIR... Deixar-se ir com as camadas que não mais dizem de nós, e que talvez nunca disseram, para afirmar outras possibilidades de si... Permitir-se trocar de pele... Renovar a pele docente, nos atritos cotidianos... Resistir...

Cambaliante e peregrina ia Razieh em potência infante à busca de um peixinho dourado que tinha barbatanas dançantes.

E o que significava o balão branco se o peixe era dourado?

Me percebi procurando um balão banco até o momento em que Razieh perdeu-se em meio aos encantadores de serpentes. Ali hipnotizei-me e me perdi também. Esqueci o nome do filme que olhava, esqueci o objeto de procura, esqueci o sujeito que 
se movia: estava então me relacionando efetivamente com a narrativa filmica, enfeitiçada...

Noto a minha demasiada preocupação em abster-me no aqui e no ali, e não no entre. Noto que muito de mim ainda pretende controlar, fixar, prender, encontrar o objeto, definir o sujeito. Deixei encantar-me, enfeitiçar-me e hipnotizar-me somente quando Razieh, na primeira oportunidade de não se domesticar ao seu próprio objetivo, perambulou junto com as serpentes e compôs seu trajeto nômade, sem destinos fixos. Foi a abertura que possibilitou minha peregrinação. Foram os atravessamentos do caminho que me instigaram a pensar em rearranjos, em possibilidades, em outras produções. Foram as relações que eu estabeleci que falam de meu percurso. Não é sobre mim ou sobre o percurso. Não é sobre mim ou filme. Não é sobre mim e a prática educacional. Tudo isso é sobre o 'entre'...<smiles>C[Hg]C</smiles>

[e...] spaços de conexão...

'[e...] ntre'...

Int $[\mathrm{e} . ..] \mathrm{r} v \mathrm{alos} .$.

[e...] spaços.intervalar [e...] s... [e...] sp a ços.interlarvar [e...] s

Não seria esse [e...] spaço intervalar, a terra sem dono por excelência?

[e...] spaço onde é possível in[ventar] a cada vez uma

$\wedge \wedge \wedge \wedge \wedge \wedge$

d o с е..................e...n cia

\section{DO QUE FOI POSSÍVEL PRODUZIR JUNTO A MOVIMENTOS DE APROPRI[AÇÕES]...}

A cada experimentação/apropriação com imagens filmicas, escritas e leituras, oportunidades de ampliação de relações foram sendo engendradas com a docência. Os arranjos produzidos estão e estarão sempre em constante abertura e movimento, pois elementos novos estão sujeitos a atuar, alguns a serem remanejados e outros colocados em suspensão. Nestas forças em cena, permutam-se 
partículas e outras composições são produzidas, assegurando o movimento dos fluxos e as energias flutuantes.

Essas experimentações cartográficas que a pesquisa buscou degustar junto da disciplina Cinema e Educação (Prática Educacional VIII) e, numa outra temporalidade, com a escrita desse artigo, desafiou-nos a exercitar um movimento do pensamento, pois nos convidou a explorar a potência da conjugação 'e' e as possibilidades inventivas que dela emergem. A intenção foi explorar a relação intensiva que a conjunção 'e' propicia, inferindo as zonas de vizinhança e suas relações de intensidade, mas, principalmente, de implicação. Pois, "uma expressão tão simples como e... pode representar o papel de tensor através de toda a linguagem" (DELEUZE; GUATTARI, 1995b, p. 44).

Ao propor cruzamentos transversais e alianças junto das apropriações com as imagens fílmicas, novas relações e arranjos passaram a ser propostos em relação à docência e a educação. Este tensionamento passou a ser propício para que pudéssemos nos aventurar e ensaiar algumas criações junto a essas experimentações. Favoreceu também a aproximação de elementos que até então, talvez, nunca tenham ficado lado a lado, permitindo, assim, que outras relações de forças pudessem se fazer presentes.

Nesse viés, não houve nada a ser descoberto, desvelado ou reproduzido, mas um terreno em constante movimento a ser cartografado, produzido e inventado. O campo de experimentações junto às imagens fílmicas, escritas e docências passou a ser redesenhado constantemente, percebendo-se como um mapa sempre inacabado, contingente e que busca ampliar as possibilidades, mesmo quando há uma necessidade de circunscrevê-lo e cerceá-lo.

O desafio colocado pela disciplina Cinema e Educação (Prática Educacional VIII) foi empreender alguns movimentos de apropriação com as imagens fílmicas que não diziam de docência e tecer algumas relações com a docência e a educação. Já nesse artigo, o exercício de apropriação se deu na provocação de experimentar e compor algo 'com' o que havia sido produzido em outra temporalidade com essas materialidades. Portanto, buscamos nessa escrita manter esse movimento, e quiçá prolongá-lo junto do/a leitor/a que se encontrar com esse texto.

\section{REFERÊNCIAS}

1. AMORIM, Antônio Carlos. Rodrigues. Fotografia, som e cinema como afectos e perceptos no conhecimento da escola. Teias, Rio de Janeiro, v. 8, n. 15, p. 1-12, jan./ dez. 2007. ISSN: 19820305. Disponível em: <https://www.epublicacoes.uerj.br/index.php/revistateias/article/download/23998/16968>. Acesso em 10 set. 2019.

2. AMORIM, Antônio Carlos. Rodrigues. Deslocamentos entre currículo e estudos de cinema experimental. Práxis Educativa, UEPG, v. 13, n. 3, p. 1025-1043, 2018. ISSN: 1809-4309. Disponível em: https://www.revistas2.uepg.br/index.php/praxiseducativa/article/view/12238 Acesso em 10 set. 2019. DOI: http://dx.doi.org/10.5212/PraxEduc.v.13i3.0022 
3. CARDONETTI, Vivien Kelling. Experiências educativas: ressonâncias de intercessões fílmicas. 2014, 156 f. Tese (Doutorado em Educação) Universidade Federal de Santa Maria, Santa Maria, 2014.

4. CARDONETTI, Vivien Kelling; GARLET, Francieli Regina; OLIVEIRA, Marilda Oliveira de. Ressonâncias de uma intercessão fílmica que impelem a problematizar a experiência educativa. Educativa, Goiânia-GO, v. 17, p. 341-366, 2014.

5. CARDONETTI, Vivien Kelling; OLIVEIRA, Marilda Oliveira de. Intercessão fílmica: um encontro sempre em vias de acontecer. Pró-posições, Unicamp, Campinas-SP, v. 30, p. 1-23, 2019.

6. CARDONETTI, Vivien Kelling; OLIVEIRA, Marilda Oliveira. Imagem fílmica: um encontro que nos convoca a pensar. Revista Digital do Laboratório de Artes Visuais, UFSM, Santa Maria-RS v. 10, p. 39-55, 2017.

7. CHIARELLI, Tadeu. Catálogo Apropriações/Coleções. Porto Alegre: Santander Cultural, 2002.

8. CORAZZA, Sandra Mara. Labirintos da pesquisa, diante dos ferrolhos. In: COSTA, Marisa Vorraber (Org.). Caminhos investigativos I: novos olhares na pesquisa em educação. 3a Ed. Rio de Janeiro: Lamparina editora, 2007. p. 103-127.

9. CORAZZA, Sandra Mara. O que se transcria em educação? Porto Alegre: UFRGS; Doisa, 2013.

10. DELEUZE, Gilles. Sur Spinoza - Cours Vincennes, cours du 24/01/1978. Tradução Francisco Traverso Fuchs. Disponível em: <https://www.webdeleuze.com/textes/194> Acesso em 04 out. 2019 .

11. DELEUZE, Gilles. O ato de criação. Tradução: José Marcos Macedo. In. Folha de São Paulo, 27/06/1999. Transcrição de conferência realizada em 1987.

12. DELEUZE, Gilles. Cinema 2 - A imagem-tempo. Tradução de Eloisa de Araújo Ribeiro. São Paulo: Brasiliense, 1990.

13. DELEUZE, Gilles. Bergsonismo. Tradução de Luiz B. L. Orlandi. São Paulo: Editora 34, 1999.

14. DELEUZE, Gilles. Diferença e repetição. $2^{\circ}$ ed. Tradução Luiz Orlandi, Roberto Machado. Rio de Janeiro: Graal, 2006.

15. DELEUZE, Gilles. Conversações. Tradução de Peter Pál Pelbart. 2.ed. São Paulo: Ed. 34, 2010. 
DELEUZE, Gilles; GUATTARI, Félix. O que é a filosofia? Tradução de Bento Prado Junior e Alberto Alonso Muñoz. Rio de Janeiro: Ed. 34, 1992.

DELEUZE, Gilles; GUATTARI, Félix. Mil platôs - Capitalismo e esquizofrenia, vol. 1. Tradução de Aurélio Guerra Neto e Célia Pinto Costa. Rio de Janeiro: Ed. 34, 1995a.

DELEUZE, Gilles; GUATTARI, Félix. Mil platôs: Capitalismo e esquizofrenia, v. 2. Tradução de Ana Lúcia de Oliveira e Lúcia Cláudia Leão. Rio de Janeiro: Ed. 34, 1995 b.

DELEUZE, Gilles; GUATTARI, Félix. Mil platôs: Capitalismo e esquizofrenia, v. 3. Tradução de Aurélio Guerra Neto et al. $4^{\text {a }}$ reimp. São Paulo: Ed. 34, 2008. Escuta, 1998.

21. FRESQUET, Adriana Mabel. Cinema e educação: Reflexões e experiências com professores e estudantes dentro e fora da escola. 1. ed. Belo Horizonte: Autêntica, 2013.

22. FRESQUET, Adriana Mabel. Cinema e educação: a lei 13006. Reflexões, perspectivas e propostas. 1. ed. Ouro Preto: Universo, 2015.

23. FOUCAULT, Michel. O cuidado com a verdade. In: Ditos e escritos V: ética, sexualidade, política. Rio de Janeiro: Forense Universitária, 2004. p. 240-251.

24. GALLO, Silvio. Diferenças, multiplicidade, transversalidade: para além da lógica identitária da diversidade. In: Alexsandro Rodrigues; Catarina Dallapicula; Sérgio Rodrigo S. Ferreira. (Orgs.). Transposições - lugares e fronteiras em sexualidade e educação. 1 ed. Vitória: Edufes, 2014. p. 185-200.

25. GUATTARI, Félix. A transversalidade (1964). In: Psicanálise e transversalidade: ensaios de análise institucional. Aparecida /SP: Ideias \& Letras, 2004. KNAAK, Bianca (Org.). A(própria)ação entr\&tantas. Santa Maria: Autor, 2005. LARROSA, Jorge. As crianças e as fronteiras: várias notas a propósito de três filmes de Angelopoulos e uma coda sobre três filmes iranianos. In: TEIXEIRA, Inês Assunção de Castro; Horizonte: Autêntica, 2006. 
29. LEITE, César Donizetti Pereira. Infância, Cinema e Educação - pesquisas com imagens para leitura além das margens. In: AMORIM, Antonio Carlos; WUNDER, Alik. (Orgs.). Leituras Sem Margens. 1 ed. Campinas SP: Leitura Crítica, 2014, v. 1, p. 205-226.

30. LEITE, César Donizetti Pereira; CHRISTOFOLETTI, Rafael. Pra quê cinema? O que pode o cinema na educação e a educação no cinema? Fronteiras de encontros. In: FRESQUET, Adriana (Org.). Cinema e Educação: A Lei 13.006 - Reflexões, perspectivas e propostas. v. 1, Belo Horizonte: Universo Produção, 2015. p. 40-50.

31. MARCELLO, Fabiana de Amorim. Cinema e educação: da criança que nos convoca à imagem que nos afronta. Revista Brasileira de Educação, ANPED, v. 13, n. 38, p. 343-356, 2008. ISSN: 1809449X. Disponível em: http://www.scielo.br/pdf/rbedu/v13n38/11.pdf. Acesso em 10 set. 2019.

32. MARTINS, Alice Fátima. Becos e trânsitos entre escola e cinema. In: MARTINS, Raimundo; TOURINHO, Irene (Orgs.) Pedagogias culturais. Santa Maria: Ed. da UFSM, 2014. p. 177-196.

33. OLIVEIRA, Marilda Oliveira. O cinema como modo de pensamento, o cinema como forma de forçar a pensar. In: MARTINS, Raimundo; TOURINHO, Irene (Orgs.) Pedagogias culturais. Santa Maria: Ed. da UFSM, 2014. p. 165-176.

OLIVEIRA, Marilda Oliveira de; MOSSI, Cristian Poletti. Cartografia como estratégia metodológica: inflexões para pesquisas em educação. Revista Conjectura: Filosofia e Educação. Caxias do Sul, v. 19, n. 3, p. 185-198, set./dez. 2014. ISSN: 2178-4612. Disponível em: <http://www.ucs.br/etc/revistas/index.php/conjectura/article/view/2156/pdf_298>. Acesso em 10 set. 2019.

OLIVEIRA, Marilda Oliveira de.; DAHMER, Carin Cristina. Entre tempos e história da arte: por um processo de apropriação. Eccos Revista Científica, São Paulo, n. 43, p. 69-83, maio./ago. 2017. ISSN: 1983-9278. Disponível em: <https://periodicos.uninove.br/index.php?journal=eccos\&page=article\&op=view\&path\%5B \%5D=737 2>. Acesso em 10 set. 2019. Doi: https://doi.org/10.5585/eccos.n43.7372

OLIVEIRA, Valeska Fortes de. Narrativas autobiográficas docentes: o cinema como dispositivo de experiencia formadora. In: BRAGANÇA, I. F. de S; ABRAHÃO, M. H. M. B.; FERREIRA, M. S. (Orgs.). Perspectivas epistêmico-metodológicas da pesquisa (auto)biográfica. 1 ed. Curitiba: CRV, 2016, v. 1, p. 145-156.

OLIVEIRA, Valeska Fortes de. ISSO AQUI TÁ VIRANDO brasil ... Cinema e produções audiovisuais no espaço da formação de professores. Revista Digital do Laboratório de Artes Visuais. Santa Maria - UFSM/RS, v. 10, n. 2, p. 92-106, maio./ago. 2017, ISSN 1983-7348. 
Disponível em: https://periodicos.ufsm.br/revislav/article/view/28789 Acesso em: 10 set. 2019. Doi: http://dx.doi.org/10.5902/1983734828789

PASSOS, Eduardo; BARROS, Regina Benevides de. Por uma política da narratividade. In: PASSOS, Eduardo; KASTRUP, Virgínia; ESCÓSSIA, Liliana (Orgs.). Pistas do método da Cartografia: pesquisa-intervenção e produção de subjetividade. $4^{a}$ Reimp. Porto Alegre: Sulina, 2015, p. 150-171.

PASSOS, Eduardo; EIRADO, André do. Cartografia como dissolução do ponto de vista do observador. In: PASSOS, Eduardo; KASTRUP, Virgínia; ESCÓSSIA, Liliana (Orgs.). Pistas do método da Cartografia: pesquisa-intervenção e produção de subjetividade. $4^{a}$ Reimp. Porto Alegre: Sulina, 2015, p. 109-130.

PELBART, Peter Pál. A potência de não: linguagem e política em Agamben. 2007. Disponível em: $<$ <ttps://territoriosdefilosofia.wordpress.com/2014/05/31/a-potencia-de-nao-linguagem-e-politicaem-agamben-peter-pal-pelbart/>. Acesso em: 10 set. 2019.

41. PELBART, Peter Pál. O avesso do niilismo - Cartografias do esgotamento. São Paulo: $\mathrm{n}-1$ edições, 2016.

42. ROLNIK, Suely. Cartografia sentimental: transformações contemporâneas do desejo. Porto Alegre: Sulina; Editora da UFRGS, 2006.

43. ROMAGUERA, Alda Regina Tognini; ODA, Pamela; AMORIM, Antônio Carlos. Em imagens, tempo e personagem do cinema pós-moderno. Revista de Estudos Universitários. Sorocaba, v. 36, n.1, p. 175-194, jun. 2010. Disponível em: < http://periodicos.uniso.br/ojs/index.php/reu/article/view/470/471 >. Acesso em 10 set. 2019.

44. VALLE, Lutiere Dalla. Aprendendo a ser docente através de filmes: possíveis trânsitos entre cinema e educação. In: MARTINS, Raimundo; TOURINHO, Irene (Orgs.) Pedagogias culturais. Santa Maria: Ed. da UFSM, 2014. p.141-163.

VASCONCELLOS, Jorge. Deleuze e o Cinema. Rio de Janeiro: Moderna Ltda, 2006.

VASCONCELLOS, Jorge. A Pedagogia da Imagem: Deleuze, Godard: ou como produzir um pensamento do cinema. Educação \& Realidade: Cinema e Educação. Porto Alegre/ UFRGS. v. 33. n.1, 2008. ISSN: 2175-6236. Disponível em: <https://seer.ufrgs.br/educacaoerealidade/article/view/6692>. Acesso em 10 set. 2019. 
47. SPINOZA, Benedictus de. Ética. Tradução de Tomaz Tadeu. $2^{a}$ ed. 5 reimp. Belo Horizonte: Autêntica Editora, 2016.

\section{Vivien Kelling Cardonetti}

Pós-Doutora pelo Programa de Pós-Graduação em Educação, Linha de Pesquisa LP4 - Educação e Artes, da Universidade Federal de Santa Maria (UFSM/RS). Membro do Grupo de Estudos e Pesquisas em Arte, Educação e Cultura (GEPAEC).

\section{Francieli Regina Garlet}

Pós-doutoranda do Programa de Pós-Graduação em Educação da Universidade Federal de Santa Maria (PPGE/UFSM) com bolsa PNPD/CAPES. Doutora e Mestre em Educação pela mesma instituição e Programa de Pós-Graduação. Graduada em Artes Visuais - Licenciatura e Bacharelado (UFSM). Membro do Grupo de Estudos e Pesquisas em Arte, Educação e Cultura (GEPAEC).

\section{Marilda Oliveira de Oliveira}

Professora Titular do Departamento de Metodologia do Ensino, Centro de Educação da Universidade Federal de Santa Maria, Rio Grande do Sul, Brasil. Doutora em História da Arte pela Universidad de Barcelona, Espanha. Coordenadora do Grupo de Estudos e Pesquisas em Arte, Educação e Cultura (GEPAEC).

\section{Como citar este documento:}

CARDONETTI, Vivien Kelling; GARLET, Francieli Regina; OLIVEIRA, Marilda Oliveira de. APROPRI[AÇÕES]: DAS FAGULHAS ACIONADAS POR ENCONTROS COM IMAGENS FÍLMICAS, ESCRITAS E DOCÊNCIAS.... Reflexão e Ação, Santa Cruz do Sul, v. 29, n. 1, p. 133-150, jan. 2021. ISSN 1982-9949. Acesso em: doi: http://dx.doi.org/10.17058/rea.v29i1.14302 